\title{
FEATURES OF LOCAL IMMUNE REACTIONS IN SKIN WITH UNDERLYING SOFT TISSUES IN PATIENTS WITH MULTIPLE SCLEROSIS
}

10.36740/WLek202010101

\author{
Olena V. Markovska, Olena L. Tovazhnyanska, Mykhailo S. Myroshnychenko, Anton S. Shapkin, \\ Nataliya 0. Nekrasova, Hanna P. Samoilova, Iryna 0. Lapshyna \\ KHARKIV NATIONAL MEDICAL UNIVERSITY, KHARKIV, UKRAINE
}

\begin{abstract}
The aim of the study is to identify the peculiarities of local immune reactions in the skin with underlying soft tissues in patients with different variants of the multiple sclerosis' course. Material and methods: The study included 35 patients, hospitalized in the neurological department of the Communal Nonprofit Enterprise of Kharkiv Regional Council «Regional Clinical Hospital» with the established diagnosis of multiple sclerosis. The patients were divided into three study groups, based on different variants of this pathology's course. Group 1 included 16 patients with relapsing-remitting type of multiple sclerosis. Group 2 included 11 patients with a secondary-progressive type of multiple sclerosis course. Group 3 included 8 patients with a primary progressive type of multiple sclerosis. Patients of all groups underwent a biopsy of the skin with underlying soft tissues in the lower third of the inner surface of the right lower leg. The comparison group (group 4) was represented by 10 autopsy cases ( 7 women and 3 men) conducted on the basis of the pathological anatomy department of the Communal Nonprofit Enterprise of Kharkiv Regional Council «Regional Clinical Hospital». There were no signs of the nervous system's pathology during life in all cases of this group. The cause of death was a dislocation of the brain stem or hematocephaly and the main disease was arteriovenous malformation or congenital aneurysm of the cerebral vessels.

The material for the morphological study was skin with underlying soft tissues. Microspecimens stained with histological and immunohistochemical methods were studied, using an Olympus BX-41 microscope. The obtained data were statistically processed, using Statistica 6.0 and Microsoft Excel 2003 programs.

Results: Survey microscopy showed that in groups 1-3 in comparison with group 4 immune cell infiltrations were more pronounced in the skin with underlying hypodermis. Significantly larger mean values of the absolute number of CD 3-, CD 20- and CD 68-positive cells were revealed immunohistochemically in groups 1-3 compared with group 4. Thus, it was found in patients with multiple sclerosis the activation of T-cell immunity, B-cell immunity and macrophage system with the development of an immune imbalance between them. Our results allow us to think about the participation of all the above immune cells in the pathogenesis of multiple sclerosis development. The revealed disorders of local immune reactions in the skin with underlying hypodermis in patients with multiple sclerosis are less pronounced in the remitting-recurrent variant of the course of the disease, more pronounced in the secondary-progressing and, especially, primary-progressing variants.

Conclusions: In patients with multiple sclerosis in the skin with underlying hypodermis activation of T-cell immunity, B-cell immunity and the macrophage system is observed with the development of an immune imbalance between them, characterized by the prevalence of the absolute number of macrophages among all immune cells. Less pronounced violations of local immune reactions in the skin with underlying hypodermis are noted in remitting-relapsing variant of multiple sclerosis course, more pronounced in a secondary-progressing and, especially, primary-progressing variants.
\end{abstract}

KEY WORDS: local immune reactions, skin with underlying soft tissues, biopsy, autopsy, multiple sclerosis, morphology

Wiad Lek. 2020;73(10):2109-2113

\section{INTRODUCTION}

Multiple sclerosis is one of the most common demyelinating-degenerative diseases of the nervous system today [1], affecting an estimated 2.3 million people worldwide. On average, disease onset and diagnosis occurs between the ages of 20 and 40 , with occurrence $2-3$ times higher in females than males [2].

The frequency of multiple sclerosis' occurrence significantly depends on geographical regions: the lowest prevalence of this disease is observed in the equatorial zone and increases with distance from it. The highest percentage of patients is detected in Northern Europe, mid-North America and southern Australia. In general, it mainly affects people of the Caucasian race, while people from Asia and Africa are less subject to the disease [3].
The main clinical manifestations of multiple sclerosis are paresis, changes in muscle tone, ataxia, nystagmus, intentional tremor, chanted speech, sensitive (including visual) and autonomic (urinary incontinence, constipation, sexual dysfunction) disorders, cognitive impairment (memory disorders, attention, thinking), formation of emotional instability, decreased intelligence, constant fatigue syndrome, etc. [4].

The cause of multiple sclerosis is still unknown. It is suspected that it is a multicomponent disease mediated by the infection-induced autoimmune process superimposed on genetic predisposition. Thus, the interaction of genetic, environmental and immune factors is involved in the etiopathogenesis of this disease [5]. Immunological 
disorders play the leading role in pathogenesis of multiple sclerosis development [6]. The concept of multiple sclerosis pathogenesis includes allocation of an initial inflammatory phase, accompanied by a phase of demyelination and then a phase of neurodegeneration [7].

Despite numerous studies by domestic and foreign scientists [8], the mechanism of multiple sclerosis development has many debatable and unresolved issues. The study of cellular and molecular mechanisms of its development is a relevant area for modern medicine, contributing to the search and development of new therapeutic, diagnostic and preventive measures.

\section{THE AIM}

To identify the peculiarities of local immune reactions in the skin with underlying soft tissues in patients with different variants of the multiple sclerosis' course.

\section{MATERIAL AND METHODS}

The study included 35 patients, among them 20 women and $15 \mathrm{men}$, hospitalized in the neurological department of the Communal Nonprofit Enterprise of Kharkiv Regional Council «Regional Clinical Hospital» with the established diagnosis of multiple sclerosis according to McDonald's criteria $(2017)[9,10]$. Average age of patients with multiple sclerosis was $34.5 \pm 1.2$ years. The patients were divided into three study groups, based on different variants of this pathology's course. Group 1 included 16 patients with relapsing-remitting type of multiple sclerosis. Group 2 included 11 patients with a secondary-progressive type of multiple sclerosis course. Group 3 included 8 patients with a primary progressive type of multiple sclerosis. On Expanded Disability Status Scale [11] in patients in group 1 the average score was $3.65 \pm 0.71$, in group $2-4.75 \pm 0.59$, in group $3-5.5 \pm 0.73$.

Patients of all groups underwent a biopsy of the skin with underlying soft tissues in the lower third of the inner surface of the right lower leg under local anesthesia with a $0.5 \%$ novocaine solution.

The comparison group (group 4) was represented by 10 autopsy cases ( 7 women and 3 men) conducted on the basis of the pathological anatomy department of the Communal Nonprofit Enterprise of Kharkiv Regional Council «Regional Clinical Hospital». There were no signs of the nervous system's pathology during life in all cases of this group. The cause of death was a dislocation of the brain stem or hematocephaly and the main disease was arteriovenous malformation or congenital aneurysm of the cerebral vessels.

The material for the morphological study was skin with underlying soft tissues, fixed in a $10 \%$ formalin solution. Compaction of tissues fixed in formalin was achieved by passing through alcohols of increasing concentration, Nikiforov liquid (96\% alcohol and diethyl ether in a 1:1 ratio), chloroform and paraffin filling. Serial sections $4-5 \times 10^{-6} \mathrm{~m}$ thick were made from blocks. For survey microscopy mi- crospecimens were stained with hematoxylin and eosin.

An immunohistochemical study (IHS) was carried out in accordance with standardized protocols, using mouse monoclonal antibodies (MCA) to CD 3 (clone SP7, marker of T-lymphocytes general population), CD 20 (clone L26, marker of B-lymphocyte), CD 68 (clone PGM1, macrophage marker). MCA were manufactured by Thermo Fisher Scientific (USA). Primary antibodies were visualized, using the UltraVision Quanto HRP detection system (Thermo Fisher Scientific, USA). The resulting microspecimens were stained with hematoxylin and eosin.

Microspecimens stained with histological and immunohistochemical methods were studied, using an Olympus BX-41 microscope (Japan). When phenotyping clones of immune cells in the field of the microscope $\times 1000$ vision, their absolute number was calculated.

The obtained data were statistically processed, using Statistica 6.0 and Microsoft Excel 2003 programs. Significant differences in the groups were evaluated, using the Mann-Whitney U-test. The differences were considered statistically significant in cases where the probability of their random nature did not exceed 5\% ( $\mathrm{p}<0.05)$.

\section{RESULTS AND DISCUSSION}

A few immune cells were found between some epithelial cells in the epidermis, in the papillary and reticular layers of the dermis mainly around the vessels, in the hypoderm between the connective tissue fibers and perivascular in group 4 during studying the microspecimens stained with hematoxylin and eosin. Among the immune cells during IHS CD 3-, CD 20-, CD 68-positive cells were detected, the average values of the absolute number of them were $3.8 \pm 0.34,3.4 \pm 0.47$ and $3.6 \pm 0.22$ respectively. The obtained results indicate that there is a dynamic balance between T-cell immunity, B-cell immunity and macrophage system in intact skin with underlying hypodermis, contributing to the maintenance of cellular homeostasis.

The presence of a few immune cells in the skin was also noted by other scientists, which allows us to regard the skin as a borderline organ of the immune system [12]. The skin is known to be capable of isolating, pressing and presenting antigens and developing a local immune response [13].

In the studied groups 1-3 it was determined both single interepithelial immune cells and their focal accumulations. In the dermis and hypodermis both focal and diffuse infiltration by immune cells was detected with predominant localization around the vessels and, especially, around the nerve fibers and directly in the thickness of the nerve fibers themselves (fig. 1).

During IHS in groups 1-3, as well as in group 4, CD 3-, CD 20- and CD 68-positive cells were detected among immune cells (fig. 2-4). The average values of the absolute number of CD 3-, CD 20-, CD 68-positive cells in group 1 were $8.6 \pm 0.38,6.2 \pm 0.55,11.4 \pm 0.38$, respectively; in group $2-11.2 \pm 0.32,6.4 \pm 0.43,15.6 \pm 0.43$; in group $3-14.8 \pm 0.61$, $5.8 \pm 0.34,19.2 \pm 0.53$. In groups $1-3$, analyzing the obtained data, we found an imbalance in the content of immune cells 


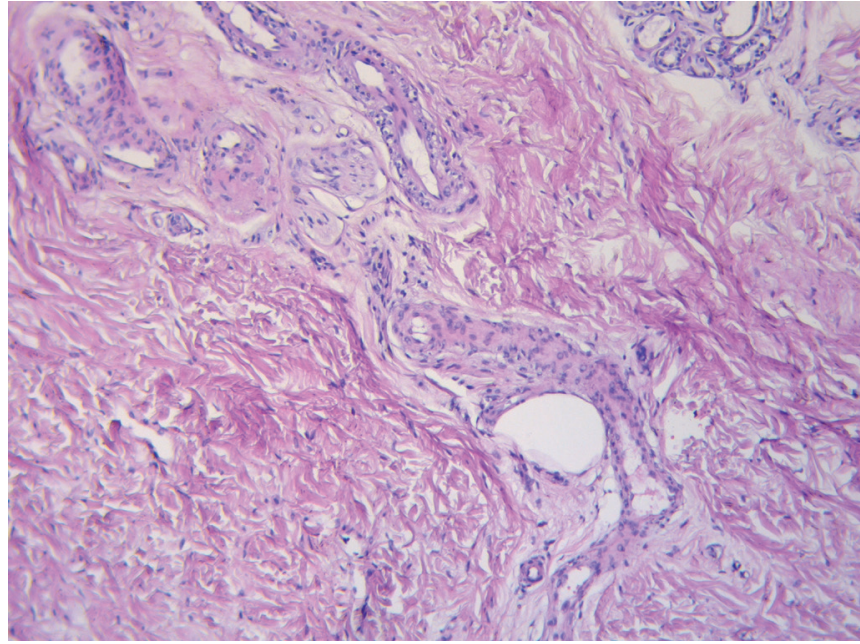

Fig. 1. Presence of immune cells in the dermis of a patient in group 2 between the connective tissue fibers, around the vessels and nerve fibers, in the thickness of the nerve fibers. Stained with hematoxylin and eosin, $\times 100$.

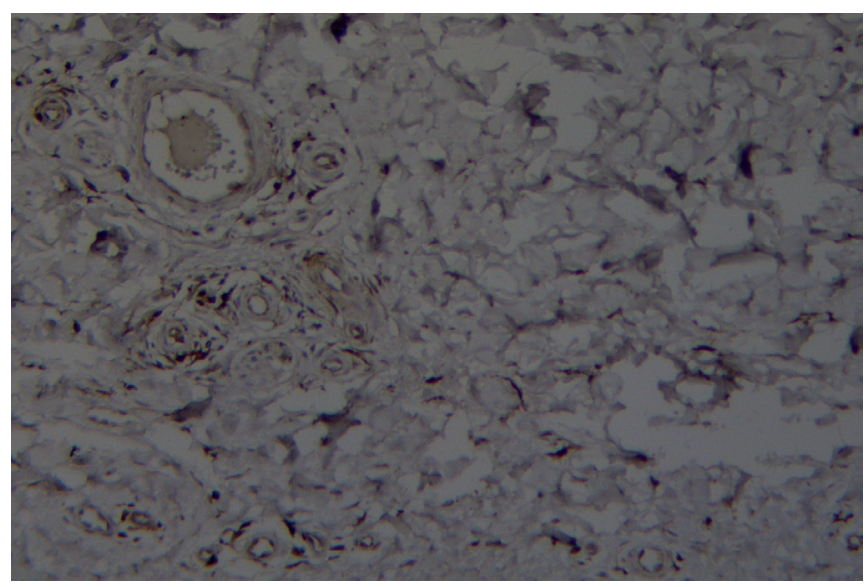

Fig. 2. CD 68-positive cells in the dermis of a patient in group 3. Immunohistochemical reaction with MCA to CD 68, × 200 .

characterized by a significant $(\mathrm{p}<0.05)$ prevalence of the absolute number of macrophage cells over the number of T-lymphocytes and B-lymphocyte.

Survey microscopy showed that in groups $1-3$ in comparison with group 4 immune cell infiltrations were more pronounced in the skin with underlying hypodermis. Significantly $(\mathrm{p}<0.05)$ larger mean values of the absolute number of CD 3-, CD 20- and CD 68-positive cells were revealed immunohistochemically in groups 1-3 compared with group 4 . Thus, it was found in patients with multiple sclerosis the activation of T-cell immunity, B-cell immunity and macrophage system with the development of an immune imbalance between them. Our results allow us to think about the participation of all the above immune cells in the pathogenesis of multiple sclerosis development.

For many years, an important role in the immunopathogenesis of multiple sclerosis was assigned to T cells [14]. Thus, many scientists have described the activation of $\mathrm{T}$ cells in the bloodstream outside the central nervous system, followed by their penetration through the blood-brain barrier into the nervous tissue. Penetrated T cells, in turn,

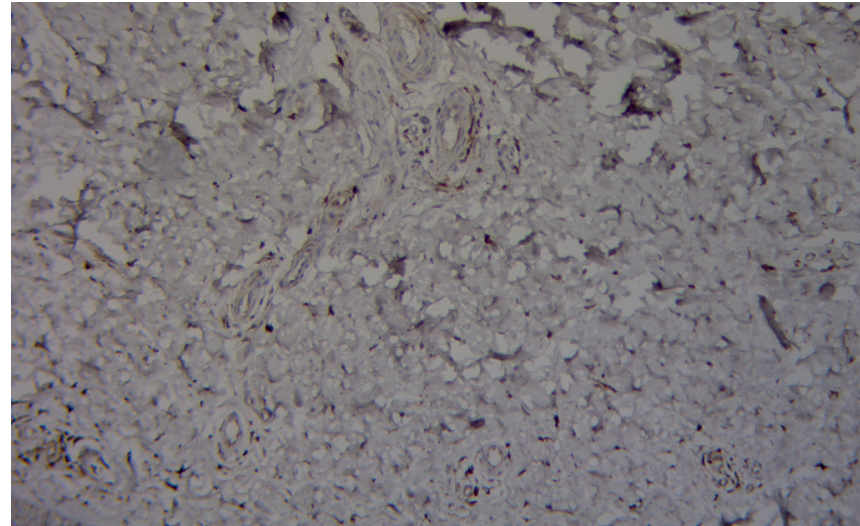

Fig. 3. CD 3-positive cells in the dermis of a patient in group 2. Immunohistochemical reaction with MCA to CD $3, \times 100$.

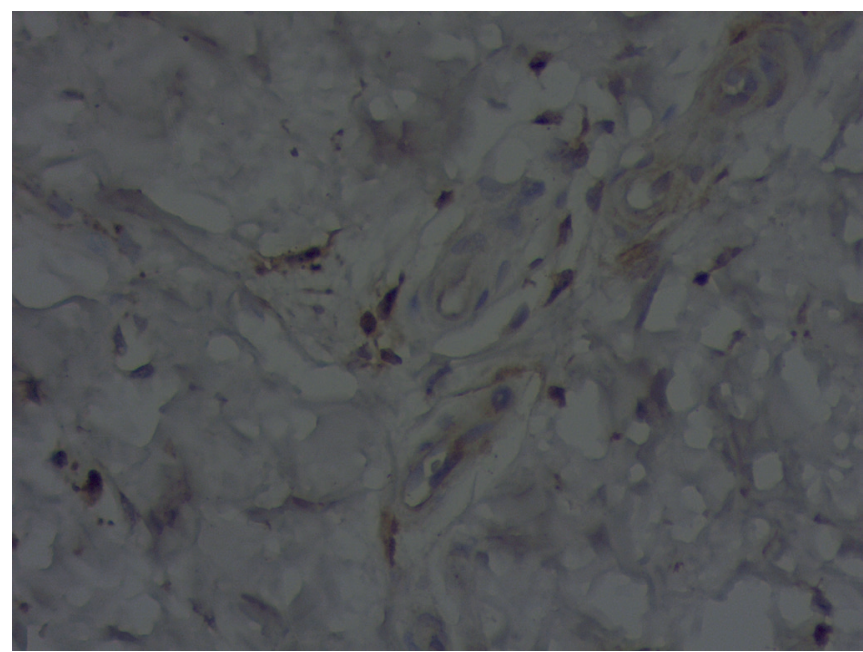

Fig. 4. CD 20-positive cells in the dermis of the patient in group 1. Immunohistochemical reaction with MCA to CD 20, $\times 400$.

begin to proliferate, attract other blood cells, including macrophages and B lymphocytes, leading to production of a large number of biologically active substances, triggering effector reactions, damaging myelin, axons, oligodendrogliocytes [3].

The role of T-cells has been revised at present. It has been recognized that B-lymphocyte plays a fundamental role in the pathogenesis of multiple sclerosis, not only as antibody-forming cells. Autoreactive B-lymphocytes in the central nervous system present autoneuroantigens to T-lymphocytes, activating and proliferating T-cells, stimulating T-cells response against nervous tissue. B-cells are capable of producing a wide range of pro-inflammatory and regulatory cytokines and growth factors (tumor necrosis factor alpha, interleukin-1, interleukin-4, interleukin-6, interleukin-10, interleukin-12, interleukin-16, interleukin-23, etc.) which modulate the migration of dendritic cells, activate macrophages, regulate the function of T-cells and provide feedback for their further activation $[15,16]$. $\mathrm{B}$-cells are involved in the formation and preservation of ectopic intramingeal lymphoid follicle-like structures associated with the progression of cortical neurodegeneration and a more aggressive course of multiple sclerosis $[5,17]$. 
Macrophages are a highly plastic, highly diverse population of cells with a multifaceted role in the normal immune response as well as in the disease. Several different phenotypical and functional subpopulations exist as a result of their activation status, influenced by environmental signals. The two most polarized phenotypes are classically activated (M1) with cytotoxic and pro-inflammatory properties and the alternatively activated (M2) macrophages, involved in tissue repair by producing extracellular matrix molecules and anti-inflammatory cytokines [18]. Studies by foreign scientists have shown a primary role of macrophages in the development of multiple sclerosis, among which the M2 phenotype prevailed over M1 [19].

Given the participation of various immune cells in the development of multiple sclerosis, morphological studies have identified patterns of pathological changes, ranging from T-cell, macrophage-mediated to B-cell demyelination. It is noted that one patient can have both, one specific mechanism for the development of demyelination and a combination of several mechanisms [20].

Multiple sclerosis is known to have a fairly pronounced staged character, i.e. its course includes periods of exacerbation (appearance of new symptoms and worsening neurological condition), which are replaced by remissions (a decrease in the severity of available symptoms or their regression and a clear improvement in the neurological condition). According to the ratio of these phases, their intensity and duration, several variants of multiple sclerosis course are distinguished [4]. The most frequent variant of its course is remitting-relapsing, characterized by periods of exacerbation, replaced by periods of complete recovery or partial improvement, while the clinical symptoms of the patient do not increase between periods of exacerbation. The secondary progressive variant of multiple sclerosis course initially proceeds like a remitting-relapsing variant with a gradual progression of clinical symptoms, with no clear periods of remission. The primary progressive variant of multiple sclerosis is characterized by a steadily progressive increase in neurological symptoms from the very beginning of the disease development, which quickly leads to a patient's disability [20].

In a comparative analysis of the obtained data in groups $1-3$, we have noted that from group 1 to group 3 the average values of the absolute number of CD 3-and CD 68-positive cells increased significantly $(\mathrm{p}<0.05)$, and the average values of the absolute number of $\mathrm{CD} 20$-positive cells did not change noticeably $(p>0.05)$. Thus, the revealed disorders of local immune reactions in the skin with underlying hypodermis in patients with multiple sclerosis are less pronounced in the remitting-recurrent variant of the course of the disease, more pronounced in the secondary-progressing and, especially, primary-progressing variants.

\section{CONCLUSIONS}

In patients with multiple sclerosis in the skin with underlying hypodermis activation of T-cell immunity, B-cell immunity and the macrophage system is observed with the develop- ment of an immune imbalance between them, characterized by the prevalence of the absolute number of macrophages among all immune cells. Less pronounced violations of local immune reactions in the skin with underlying hypodermis are noted in remitting-relapsing variant of multiple sclerosis course, more pronounced in a secondary-progressing and, especially, primary-progressing variants.

\section{REFERENCES}

1. Hryhorova I.A. Sistemnye narushenija u bolnyh rassejannym sklerozom. Systemic disorders in patients with multiple sclerosis. International medical journal. 2018;3:45-49. (Ru)

2. Nally F.K., Santi C.D., McCoy C.E. Nanomodulation of macrophages in multiple sclerosis. Cells. 2019;8(543): doi:10.3390/cells8060543.

3. Irzhayeva L.N., Demyashkin G.A., Irzhayev D.I. et al. Pro- i protivovospalitelnye biomarkery rassejannogo skleroza (molekuljarnobiologicheskij aspekt). Pro- and anti-inflammatory biomarkers for multiple sclerosis (molecular biological aspect). Crimea journal of experimental and clinical medicine. 2017;7(2):142-154. (Ru)

4. Pivneva T.A. Mehanizmy demielinizacii pri rassejannom skleroze. Mechanisms of demyelination in multiple sclerosis. Neurophysiology. 2009;41(5):429-437. (Ru)

5. Lazibat I., Majdak M.R., Županić S. Multiple sclerosis: new aspects of immunopathogenesis. Acta Clinica Croatica. 2018;57:352-361.

6. Baidina T.V., Kuklina E.M., Selyanina N.V. et al. Issledovanie patogeneza rassejannogo skleroza kak osnova ego targetnoj terapii. Study of multiple sclerosis pathogenesis as the basis of its targeted therapy. Perm medical journal. 2018;35(1):27-32. (Ru)

7. Trifonova 0.V., Zavalishin I.A. Sovremennye metody patogeneticheskoj terapii rassejannogo skleroza. Modern methods of pathogenetic therapy of multiple sclerosis. Farmateca. 2009;7:51-54. (Ru)

8. Dobsona R., Giovannonib G. Multiple sclerosis - a review. European Journal of Neurology. 2019;26:27-40.

9. National Multiple Sclerosis Society. Revised «McDonald criteria» expected to speed the diagnosis of multiple sclerosis. ScienceDaily. 2017;22: https://www.sciencedaily.com/releases/2017/12/171222111412.htm.

10. Thompson A.J., Banwell B.L., Barkhof F. et al. Diagnosis of multiple sclerosis: 2017 revisions of the McDonald criteria. The Lancet neurology. 2018;17(2):162-173.

11. Kurtzke J.F. Rating neurologic impairment in multiple sclerosis: an expanded disability status scale (EDSS). Neurology. 1983;33:1444-1452.

12. Borovik T.E., Makarova S.G., Darchiya S.N. et al. Kozha kak organ immunnoj sistemy. Skin as an organ of the immune system. Pediatria. 2010;89(2):132-136. (Ru)

13. Kozlova N.N., Prokopenko V.D. Kozha kak immunnyj organ. The skin as an organ of immunity. Immunopathology, allergology, infectology. 2006;4:34-40. (Ru)

14. Zavalishin I.A., Peresedova A.V. Rassejannyj skleroz: sovremennaja koncepcija patogeneza i patogeneticheskogo lechenija. Multiple sclerosis: modern conception of pathogenesis and treatment. Annals of clinical and experimental neurology. 2007;1(1):32-40. (Ru)

15. Slobodin T. Kljuchevaja rol B-limfocitov v patogeneze rassejannogo skleroza. The key role of B-lymphocytes in the pathogenesis of multiple sclerosis. Neurology and neurosurgery. Eastern Europe. 2017;7(1):142150. (Ru)

16. Arneth B.M. Impact of B cells to the pathophysiology of multiple sclerosis. Arneth journal of Neuroinflammation. 2019;16(128): https:// doi.org/10.1186/s12974-019-1517-1. 
17. Abramova A.A., Zakroyshchikova I.V., Krotenkova I.A. et al. Jektopicheskie limfoidnye B-kletochnye follikuly pri rassejannom skleroze: rol v patogeneze zabolevanija i prognosticheskaja znachimost. Leptomeningeal B-cell follicles in multiple sclerosis: a role in the pathogenesis and prognostic value. S.S. Korsakov journal of neurology and psychiatry. 2019;119(10-12):21-27. (Ru)

18. Vogel D.Y.S., Vereyken E.J.F., Glim J.E. et al. Macrophages in inflammatory multiple sclerosis lesions have an intermediate activation status. Journal of neuroinflammation. 2013;10(35): http://www.jneuroinflammation. com/content/10/1/35

19. Cheng Y., Sun L., Xie Z. et al. Diversity of immune cell types in multiple sclerosis and its animal model: pathological and therapeutic implications. Journal of neuroscience research. 2017; 95:1973-1983.

20. Zheleznikova G.F., Scripchenko N.V., Ivanova G.P. et al. Faktory immunopatogeneza rassejannogo skleroza. Immunopathogenesis factors of multiple sclerosis. Russian journal of immunological. 2015;9/18(3):261-282. (Ru)

\section{ORCID and contributionship:}

Olena V. Markovska - 0000-0002-8759-4272 $2^{A, C, D}$

Olena L. Tovazhnyanska - 0000-0002-7551-3818 ${ }^{A, E}$

Mykhailo S. Myroshnychenko - 0000-0002-6920-8374

Anton S. Shapkin - 0000-0002-6437-4840 ${ }^{\text {, F }}$

Nataliya O. Nekrasova - 0000-0002-0900-4441 $1^{B, E}$

Hanna P. Samoilova - 0000-0003-3119-5480 B, F

Iryna O. Lapshyna - 0000-0002-7106-3880 C, E

\section{Conflict of interest:}

The Authors declare no conflict of interest.

\section{CORRESPONDING AUTHOR}

Mykhailo S. Myroshnychenko

Pathological Anatomy Department,

Kharkiv National Medical University

Str. Svetlaya 27A, apt. 70, 61129, Kharkiv, Ukraine

tel: +380501699763, +380961033038

e-mail:msmyroshnychenko@ukr.net

Received: 22.04 .2020

Accepted: 17.08 .2020

A - Work concept and design, B - Data collection and analysis, C - Responsibility for statistical analysis,

D-Writing the article, $\mathbf{E}$-Critical review, $\mathbf{F}$ - Final approval of the article 